\title{
The Implementation of Management Accounting Practices (Maps): Managers's Perception
}

\author{
Renna Magdalena
}

Accounting Study Program Universitas Pelita Harapan, Surabaya Campus

\begin{abstract}
The purpose of this study is to investigate the implementation of Management Accounting Practices (MAPs) in Food Industries in Bali Island. MAPs in this Study will be measured by Costing Systems, Performance Measurement System (PMS), Decision Support System (DSS). The data for this study was obtained from questionnaire distributed to 100 Finance and Accounting managers. Descriptive Statistics frequency of using MAPs will be the main discussion of this study. Further interviews were also conducted to get more detailed picture of MAPs. Current state of MAPS at Food Industries may provide directions to other industry players regarding current MAPS trends and future trends. Accountant educators can get an idea of managerial accounting skills to prioritize for teaching prospective accountants.
\end{abstract}

Keywords: Costing Systems, Performance Measurement System (PMS), Decision Support System (DSS) and Management Accounting Practices (MAPs)

\section{Introduction}

Kaplan and Norton (1996) likened a company as a vehicle. Small vehicles such as cars do not need a lot of indicators panes (for example: only need a gasoline panel and speed panel), while larger vehicles such as an airplane, will need more panels as indicators in the cockpit (example: air pressure panel, gravity panel, speed panel, time panel, weather stability panel). Running a company is like running a vehicle. As the company size is increasing, the decision makers in the company will need indicators that are increasingly complex. Not only financial data indicators but a combination of financial data and non-financial data as well. It will require increasingly complex performance measurements, which include Financial Performance and NonFinancial Performance.

Accounting as a system that processes economic transactions as input data for reports to be used in decision making, provides a major contribution to measure company performance. According to Hansen and Mowen (2009) there are a few differences between Management Accounting and Financial Accounting which can be seen in Table 1.

Table 1: Differences in Management Accounting and Financial Accounting

\begin{tabular}{|l|l|l|}
\hline & Management Accounting & Financial Accounting \\
\hline Scope & Internal Focus & External Focus \\
\hline $\begin{array}{l}\text { Information } \\
\text { Limitation }\end{array}$ & There is no binding standard & $\begin{array}{l}\text { Must follow certain rules from } \\
\text { external parties }\end{array}$ \\
\hline Time Orientation & Einancial and non-financial information, & $\begin{array}{l}\text { Financial information that is } \\
\text { objective }\end{array}$ \\
\hline Broad Information & $\begin{array}{l}\text { Internal evaluations and decisions are based } \\
\text { on very detailed information }\end{array}$ & $\begin{array}{l}\text { Information about the } \\
\text { company as a whole }\end{array}$ \\
\hline $\begin{array}{l}\text { Correlation with Other } \\
\text { Sciences }\end{array}$ & Correlation with Other Sciences & More independent \\
\hline
\end{tabular}

Source: Hansen dan Mowen (2009) 
From Table 1, it can be seen that Management Accounting adopts Financial and non-Financial Information. The times have led companies to adopt more modern Management Accounting Practices (MAPs). At present, MAPs have included Financial and Non-Financial information which aims to provide important information at the operational level of a company (Ahmad, 2017). Over the past three decades, a number of innovative Management Accounting practices have been developed in various industries, especially the manufacturing industry. Many experts argue that innovative methods have influenced the whole process in Management Accounting (planning, controlling, decision making, and communication) and have shifted their focus from the system which is "simple" to a more "modern" system in determining costs and in increasing resources (Abdel-Kader and Luther, 2008).

By looking at the benefits of Management Accounting as a basis for company decision making, this study was conducted to find out the actual practice of applying management accounting techniques in the company. Ittner and Larcker (2002) in Abdel-Kader and Luther (2008) said that it would be very difficult for a science such as management accounting to develop, without knowing the actual practices in the industry. There must be studies to track the development of the actual practices of management accounting science.

Tourism industry is a never-ending business in Bali. Consequently, other businesses that support the main tourism industry, such as food and beverage, hotels and restaurants are also extremely on demand. Food Industry in Bali is now moving from traditional industry to mass industry (but still maintaining local wisdom). Traditional foods that were once packaged in a home industry with minimal quality standards are now heading towards modernity. More and more food is packaged with guaranteed quality standard hygiene. As not many studies have been conducted in this sector, makes the food industry a useful research site for this investigation.

Previous research conducted by Ahmad (2017) has examined the relationship between MAPs and company performance in large companies and small companies. Ogungbade et al., (2017) conducted research in Nigerian manufacturing companies. In Nigeria, technology, firm strategy, and firm culture are factors that cause MAPs to be adopted in companies, especially manufacturing companies. Abdel-Kader and Luther (2008) also conducted research on MAPs in the UK to examine the impact of company characteristics on MAPs, and the results explained that the application of company characteristics could affect MAPs. As previous researches on MAPs were carried out in Malaysia, Nigeria and the UK, this research will focus on the Food Industry in Tourism Area on the Island of Bali.

Comprehensive literature review of MAPs are presented in Section 2. Section 3 presents the research methodology used in this study and Section 4 discusses the results and their significances. Finally, Section 5 concludes this study by emphasizing the key findings and suggesting area of future research.

\section{Literature Review}

Management Accounting are one part of accounting that can provide more complex information besides financial information. Hansen and Mowen (2013) state that Management Accounting is the process of identifying, collecting, measuring, classifying, and reporting information that is useful for internal users in planning, controlling, and making decisions. Financial accounting generally presents information about the company as a whole. Because the reports produced by financial accounting will be used by various parties, so the preparation must be based on generally accepted criteria. While management accounting information is needed by the management of a company (for internal purposes), and thus it is not limited by a principle that is generally accepted. The main criteria for management accounting are benefit. Therefore, management accounting is not based on a principle that must be accepted, but on the criteria set by the management concerned.

According to Hansen and Mowen (2006) Management Accounting has three general objectives, namely:

1. Providing information that is used in calculating cost of goods, products, and other purposes desired by management.

2. Providing information that is used in planning, controlling, evaluating, and continuously improving.

3. Provides information for decision making. 
There are many measurements that can be used to measure the Management Accounting Practices (MAPs), This study will limit the scope of measurement of MAPs by the Costing System, Performance Measurement System (PMS), Decision Support System (DSS).

\section{Costing System:}

1. Job Order Costing is a method of determining the cost of products that collect and charge fees for certain jobs/certain orders (Simamora, 2012).

2. Process Costing is a method in which production costs are collected for a certain period and the cost of production per unit of product produced in that period is calculated by dividing the total cost of production for that period by the number of product units produced in the relevant period.

3. Full Costing is a method of determining the cost of production that takes into account all elements of production costs into the cost of production (Mursyidi, 2010).

4. Variable Costing is a method of determining variable costs, namely determining product costs by entering all variable costs only (Salman, 2013).

5. Activity-Based Costing System can be defined as a system of cost calculation approaches based on existing activities in the company to produce products or services (Dunia et al., 2012 and Simamora, 2012).

\section{Performance Measurement System:}

1. Operating Income is the company's operating profit deducted by the cost of production.

2. Variance Analysis is a systematic process to identify, report, and explain the variance or deviation of the actual results from the expected or budgeted results (Single, 1995).

3. Kesuma (2009) states that Sales Growth is an increase in the number of sales from year to year or from time to time.

4. Cash Flows are the amount of cash that comes out and in as a result of company activities that go in and out.

5. Number of Customer Complaints is the number of complaints from customers who are not satisfied with the products the company offers.

\section{Decision Support System (DSS)}

1. Break Even Analysis is an analysis conducted to determine the profit and loss of a company based on fixed costs, variable costs, profits, and the volume of activities Syamsudin (2011).

2. Stock Control Model is a control over inventory. Inventory in the warehouse must controlled, so that it can maintain the quantity and quality of inventory.

3. Product Profitability Analysis is a profit analysis of the products produced by the company. The profit of the product proves the quality and productivity of a good company.

4. Customer Profitability Analysis is an analysis of profits from customers. Customers who are loyal to the products of the company prove that the quality offered is in accordance with customer expectations.

\section{Methodology}

This study data were obtained from the distribution of questionnaire and interviews conducted in 100 Finance and Accounting managers (Middle Management to Top Management), whom have worked in the company as managers for at least three years and worked in the food industry who employs 50 people and above in Denpasar Bali. The questionnaires were distributed to 250 managers and 100 questionnaires returned. The questionnaires contained a statement regarding the frequency of the application of MAPs (Costing Systems, Performance Measurement System (PMS), Decision Support System (DSS) and Strategic Management Accounting (SMA). The scale used was the 1-4 scale (S1 = Never, S2 = Rare S3 = Often S4 = Always). The data were obtained by two methods, from questionnaires followed by further interviews to obtain more detailed picture of accounting management practices. The results of the questionnaires will be processed in descriptive statistics to get a picture of MAPs usage. Further interviews were also conducted to get more detailed picture of MAPs.

\section{Results}

This chapter will present the results of the questionnaires distributed and returned for twelve weeks. 
Table 2: Costing System Data

\begin{tabular}{|c|c|c|c|c|c|}
\hline \multirow{2}{*}{ No. } & \multirow{2}{*}{ STATEMENTs: Costing System } & \multicolumn{4}{|c|}{ SCOREs } \\
\hline & & S1 & $\mathbf{S 2}$ & $\mathbf{S 3}$ & S4 \\
\hline 1 & Job Order Costing & $4 \%$ & $15 \%$ & $49 \%$ & $32 \%$ \\
\hline 2 & Process Costing & $4 \%$ & $39 \%$ & $31 \%$ & $26 \%$ \\
\hline 3 & Full Costing & $0 \%$ & $18 \%$ & $42 \%$ & $40 \%$ \\
\hline 4 & Variable Costing & $28 \%$ & $48 \%$ & $21 \%$ & $3 \%$ \\
\hline 5 & Activity Based Costing & $23 \%$ & $63 \%$ & $5 \%$ & $9 \%$ \\
\hline
\end{tabular}

(S1=Never, S2= Rare S3=Often S4 =Always)

Implementation of the Costing system must be adjusted to variations in the company, for example; the size of the company, the complexity of the production system, and product variations of the company, so that the use of each method in the Costing System is adjusted according to company needs. Costing in a Food company is not a foreign concept, because the Food Industry is oriented towards products offered at prices that have been set at the beginning. Therefore, the Accounting and Finance Staff are familiar with the Costing System. Costing System in fact has a function so that cost management in a company can be more directed. Costing System is a combination of one or more costs that regulate costs in a company that can provide benefits for more effective and efficient performance. Based on Table 2 it can be seen:

1. Job Order Costing has advantages in companies that produce different product variances as in the Food Industry, because it can calculate and accumulate costs in accordance with the orders obtained. The cost calculation is calculated based on the cost of raw materials, direct labor costs and factory overhead costs. This enables the company to control the cost items that are less important by way of cost efficiency. From 100 Finance and Accounting managers, it is found that the use of Job Order Costing is often used at $49 \%$ and always used at $32 \%$. It can be concluded that the majority of financial managers have used Job Order Costing in their cost calculations.

2. Process Costing, is very good to be done at companies that produce products with the same variants en masse and carried out continuously. From 100 Finance and Accounting managers, it is known that the use of Process Costing is often used at $31 \%$ and always used at $26 \%$. Process Costing is rarely used at $39 \%$ and has never been used at $4 \%$. From these data it can be concluded that the majority of financial managers have used Process Costing in their cost calculations.

3. Full Costing is more directed to external party financial reporting, because it can provide more complete reporting. From 100 Finance and Accounting managers, it is known that the use of Full Costing is often used at $42 \%$ and always used at $40 \%$. Full Costing is rarely used at $18 \%$ and never used at $0 \%$. From these data it can be concluded that the majority of financial managers have used Full Costing in their cost calculations.

4. Variable Costing is more directed at internal company financial reporting, because it can provide shortterm financial reporting. This short-term financial reporting can be useful for top management to make short-term strategic decisions of the company. From 100 Finance and Accounting managers, it is known that the use of Variable Costing is often used at $21 \%$ and always used at $3 \%$, Variable Costing is rarely used at $48 \%$ and never used at $28 \%$. From these data it can be concluded that the majority of financial managers rarely use Variable Costing in their cost calculations.

5. Activity Based Costing ( $\mathrm{ABC}$ ) is determination of prices that are adjusted to the activities that occur to help companies to be more careful in calculating the cost of production. Existing cost behavior can be clearly traced based on the activities that occur, so that activities that do not add value to the product can be eliminated. From 100 Finance and Accounting managers, it is known that the use of ABC is often used at $5 \%$ and always used at $9 \%$. ABC rarely used by $63 \%$ and never used by $23 \%$. From these 
data it can be concluded that the majority of financial managers rarely use $\mathrm{ABC}$ in their cost calculations.

Logically, Food Industry is a price-oriented company, because the products will be marketed and pricing is a crucial factor in a company. The policy in determining the price will affect the company's profits and losses. Viewed from the financial side, determining prices that are adjusted to market conditions will boost sales figures, so that it will generate large profits. Large profits indicate financial success at the company, and consequently, financial success at the company will make the company realizes the importance of implementing a costing system.

From interviews conducted to confirm the results of descriptive statistics, it is known that Finance and Accounting managers mostly use Full Costing because this is the costing required in the Financial Statements. The distinctive feature of the Food Industry is that although they produce it en masse, they also accept special orders at fixed prices. Therefore they often do Process Costing and Job Order Costing. It is also known that Finance and Accounting managers in the Food Industry are reluctant to use variable costing and $\mathrm{ABC}$ because company leaders are more concerned with and trust the calculation of costs contained in the Financial Statements as actual costs. Finance and Accounting managers realize that the calculation using Variable costing and $\mathrm{ABC}$ is actually able to provide a more precise calculation of costs in each product produced, the only problems are the availability of staff to calculate and the absence of Support from Top Management to do the calculation with Costing, causing Managers Finance focuses more on calculating the cost with Full Costing, Job Order Costing and Process Costing.

Table 3: Performance Measurement System (PMS) Questionnaire Results

\begin{tabular}{|l|l|l|l|l|l|}
\hline \multirow{2}{*}{ No. } & STATEMENTs & \multicolumn{2}{|l|}{ SCOREs } \\
\hline & Performance Measurement System (PMS) & S1 & S2 & S3 & S4 \\
\hline 1 & Operating Income & $\mathbf{0 \%}$ & $\mathbf{1 0 \%}$ & $\mathbf{2 5 \%}$ & $\mathbf{6 5 \%}$ \\
\hline 2 & Variance Analysis & $\mathbf{2 \%}$ & $\mathbf{1 6 \%}$ & $\mathbf{6 7 \%}$ & $\mathbf{1 5 \%}$ \\
\hline $\mathbf{3}$ & Sales Growth & $\mathbf{1 \%}$ & $\mathbf{1 4 \%}$ & $\mathbf{1 6 \%}$ & $\mathbf{7 0 \%}$ \\
\hline $\mathbf{4}$ & Cash Flows & $\mathbf{0 \%}$ & $\mathbf{1 1 \%}$ & $\mathbf{7 4 \%}$ & $\mathbf{1 5 \%}$ \\
\hline $\mathbf{5}$ & Number of Costumer Complaints & $\mathbf{0 \%}$ & $\mathbf{2 1 \%}$ & $\mathbf{6 5 \%}$ & $\mathbf{1 4 \%}$ \\
\hline
\end{tabular}

Performance Measurement System (PMS) helps to evaluate performance, therefore PMS has a very important role in the company. A good PMS will direct and provide guidance to the company to perform better, so that it can generate more profits which will increase Financial Performance in the company. A business (organization) should have performance measurements that really show the level of performance achieved, and be able to show how successful the achievement of objectives at each level (Suartika, 2007). PMS is used to identify various wastes as well as encourage efforts to reduce wastes. Based on Table 3 it can be seen:

1. Operating Income is very important to calculate, because in addition to being required in the financial statements, the company can find out how much operating profit has been obtained, so that it will be assessed whether the profit obtained is in accordance with the target. From 100 Finance and Accounting managers, it is known that the use of Operating Income is often used at $65 \%$ and always used at $25 \%$, Operating Income is rarely used at $10 \%$ and never used at $0 \%$. From these data it can be concluded that all financial managers use Operating Income in measuring performance.

2. Variance Analysis is done to see the difference between the target and the realization of each cost determination. The difference obtained can be allocated to other cost items so that no waste occurs. Existing differences can also be a focus of improvement. From 100 Finance and Accounting managers, it is known that the use of Variance Analysis is often used at $67 \%$ and always used at $15 \%$, Variance Analysis is rarely used at $16 \%$ and never used at $2 \%$. From these data it can be concluded that the majority of financial managers use Variance Analysis in measuring performance. 
3. Sales Growth is performed to compare sales growth from year to year, so companies can be aware of when there is a slowdown in growth or a decline in growth. From 100 Finance and Accounting managers, it is known that the use of Sales Growth is often used at $70 \%$ and always used at $14 \%$, Sales Growth is rarely used at $16 \%$ and never used at $0 \%$. From these data it can be concluded that all financial managers use Sales Growth in measuring performance.

4. Cash Flow calculations can help companies to analyze all cash flow plans related to the company's financial plan. This can help managers in making decisions based on Financial policy. From 100 Finance and Accounting managers, it is known that the use of Cash Flow is often used at $74 \%$ and is always used at $15 \%$, Cash Flow is rarely used at $11 \%$ and has never been used at $0 \%$. From these data it can be concluded that all financial managers use Cash Flow in measuring performance.

5. Customer complaint is a form of expression of disappointment in the company's products or services. Customer complaints will give a bad image to the company's name. A bad image will make Costumer switch to competitors and leave the products the company offers. This can be fatal when ignored, therefore the calculation of Number of Customer Complaints is important. From 100 Finance and Accounting managers, it is known that the use of Number of Customer Complaints is often used at $65 \%$ and always used at $14 \%$, Number of Costumer Complaints is rarely used at $21 \%$ and never used at $0 \%$. From these data it can be concluded that all financial managers use Number of Customer Complaints in measuring performance.

As Food Industry is a company oriented to the development of a product, the waste that occurs in the production process has a very large impact on the company's financials. For every company performance, when waste is not considered properly it may incur a great loss. Achievement of these performance measures can make Financial Performance in the company better, and consequently, better Financial Performance in the company will make the company more aware of the importance of implementing PMS in the company.

From the results of interviews conducted to confirm the results of descriptive statistics, it is known that Finance and Accounting managers have used the Performance Measurement System properly because its role as a performance gauge is highly recognized by company owners. Therefore they are required to provide reports on periodic performance measurements by company owners.

Table 4: Decision Support System (DSS) Questionnaire Results

\begin{tabular}{|l|l|l|l|l|l|}
\hline No. & \multicolumn{1}{|c|}{ STATEMENTs } & \multicolumn{4}{c|}{ SCOREs } \\
\hline & Decision Support System (DSS) & S1 & S2 & S3 & S4 \\
\hline 1 & Break-Even Analysis & $\mathbf{0 \%}$ & $\mathbf{1 1 \%}$ & $\mathbf{5 1 \%}$ & $\mathbf{3 8 \%}$ \\
\hline 2 & Stock Control Model & $\mathbf{1 3 \%}$ & $\mathbf{2 5 \%}$ & $\mathbf{3 2 \%}$ & $\mathbf{3 0 \%}$ \\
\hline 3 & Product Profitability Analysis & $\mathbf{0 \%}$ & $\mathbf{1 6 \%}$ & $\mathbf{2 4 \%}$ & $\mathbf{6 0 \%}$ \\
\hline 4 & Costumer Profitability Analysis & $\mathbf{6 6 \%}$ & $\mathbf{2 1 \%}$ & $\mathbf{8 \%}$ & $\mathbf{5 \%}$ \\
\hline
\end{tabular}

Decision Support System (DSS) is not directly intended to make decisions, but provides guidance for decision making. Top management plays major role in decision making, while Middle and Low Management play minor role in decision making. This shows that Low Management is not too involved in DSS or involved but does not feel involved, because of the minor role that makes it invisible. When inconsistencies occur in the market, then what will be done is quick decision making. Based on Table 4 it can be seen:

1. Break-Even Analysis is important to do in the company because the company can see the number of profits and losses in the company, to enable top management to make decisions in accordance with existing data. Decisions from managers that are fast and precise can make productivity figures go up, so that existing losses can be anticipated quickly using existing profit benchmarks. From 100 Finance and Accounting managers, it is known that the use of Break-Even Analysis is often used at $51 \%$ and always used at 38\%, Break-Even Analysis is rarely used at $11 \%$ and never used at $0 \%$. From these data it can be concluded that all financial managers use Break-Even Analysis to support decision making. 
2. Stock Control Model is carried out to facilitate top management decision making. The Stock Control Model also enables companies to use resources in accordance with production capacity, so there is no waste of inventory. From 100 Finance and Accounting managers, it is known that the use of the Stock Control Model is often used at 32\% and always used at 30\%, the Stock Control Model is rarely used at $25 \%$ and has never been used at $13 \%$. From these data it can be concluded that the majority of financial managers use the Stock Control Model to support decision making.

3. Product Profitability Analysis is an analysis of the profit from the products produced by the company. Profit from the product shows the quality and productivity of a good company. From 100 Finance and Accounting managers, it is known that the use of Product Profitability Analysis is often used at $24 \%$ and always used at 60\%, Product Profitability Analysis is rarely used at 16\% and never used at $0 \%$. From these data it can be concluded that all financial managers use Product Profitability Analysis to support decision making.

4. Customer Profitability Analysis is an analysis of profits from customers. Customers who are loyal to the products of the company prove that the quality offered is in accordance with customer expectations. From 100 Finance and Accounting managers, it is known that the use of Customer Profitability Analysis is often used at $8 \%$ and always used at 5\%, Customer Profitability Analysis is rarely used at $21 \%$ and never used at $66 \%$. From these data it can be concluded that most financial managers do not use Customer Profitability Analysis in supporting decision making.

Quality of the decisions made will affect the condition of the company. Competitions in the business world require a company to be very careful in making decisions. DSS is assisted by computers but it is not replacing the manager's function. DSS helps managers in making decisions at the company with a more modern system. Erratic consumer behavior becomes a very complex problem in decision making, therefore companies must proactively master information to compete for market share. Data and information become very important in implementing DSS, because the system will only process the data and information needed. The portion of Top Management in decision making can also encourage a relationship between DSS and Non-Financial Performance, this is because Top Management is more directed at making decisions that aim to support Non-Financial Performance in the company. It can be concluded that DSS can be a factor in boosting the quality and quantity of a company with a governing system.

From interviews conducted to confirm the results of descriptive statistics, it was found that the use of Customer Profitability Analysis as a DSS is considered to be time consuming to work with consumers from various Food Industries. Therefore, decisions are only based on current market conditions, so that the company's condition remains stable and no less competitive. Duties and responsibilities of superiors can also be an additional factor, superiors basically have a large duty and responsibility to achieve financial targets. The duties and responsibilities of a Finance and Accounting manager are managing accounting functions into accounting information, coordinating all staff performance, coordinating all of the company's finances, managing company taxes etc. The many duties and responsibilities of a Finance and Accounting manager will make DSS not implemented, because when there is something that must be decided quickly, managers will tend to make decisions according to their instincts. All these factors contribute to make Customer Profitability Analysis as part of DSS become something that is less important in the company.

\section{Conclusions}

This study aims to get an overview of Managerial Accounting Practices (MAPs) in the Food Industry in Bali. Current state of MAPS at Food Industries will provide directions to other industry players regarding current and future MAPS trends. In this research, the parts of Costing Systems that are most rarely done by Finance and Accounting Managers in the Food Industry in Bali are Variable Costing and Activity Based Costing. This is mainly due to lack of support from Top Management, where Top Management only tends to focus on Costing related to Financial Statements. In the Performance Measurement System all tools tend to be used by most managers. In the Decisions Support System, Customer Profitability analysis is worth paying attention to. Indeed, consumers for the food industry are so diverse that it is difficult to do a whole customer analysis, but analysis can be done for the type of customer who forms a large proportion of purchases. Overall MAPs are considered to have a very important role in supporting the company's success. Accountant educators can get an idea of what managerial accounting skills they should prioritize to be taught to prospective accountants. The application of MAPs in general is a supporter of Firm Performance. Costing 
System, Performance Measurement System (PMS) and Decision Support System (DSS) must continue to be upgraded in line with evolving times and by monitoring of the company's internal and external business.

This research has several limitations in its implementation. The recommendations for future research can complement the limitations of this study. This study only used primary data collection methods through questionnaires and interviews with respondents who fit the criteria. Using this data collection method, the conclusions drawn are only based on respondents' perceptions derived on the respondent knowledge about the company conditions. It is better for further research to explore other methods, such as observation to obtain in depth data to strengthen the explanation of Management Accounting Practices (MAPs) in the company. This study only uses three measurements to measure Management Accounting Practices (MAPs), it is better for further research to provide additional reasons to more accurately identify reasons why MAPs are adopted in the company, such as identifying Technology, Firm Strategy, and Firm Culture in the company. The scope of research is only in the Food Industry in Bali, therefore further research is expected to broaden the scope of studies such as manufacturing companies throughout Indonesia, in order to obtain different views from a variety of companies, to be able to see the role of Management Accounting Practices (MAPs) that can help improve Firm Performance.

\section{REFERENCES}

[1.] Abdel-Kader, M., \& Luther, R. (2008). The Impact of Firm Characteristics on Management Accounting Practices: UK-based Emperical Analysis. British Accounting Review, 40, 2-27.

[2.] Ahmad, K. (2017). The Implementation of Management Accounting Practices and its Relationship with Performance in Small and Medium Enterprises. International Review of Management and Marketing, 7, 342-353.

[3.] Hansen, M. E., \& Mowen, M. M. (2006). Akuntansi Manajerial (7 $7^{\text {th }}$ ed.). Terjemahan oleh Denny Arnos Kwary. Jakarta: Salemba Empat.

[4.] Hansen, M. E., \& Mowen, M. M. (2009). Akuntansi Manajerial ( $8^{\text {th }}$ ed.). Terjemahan oleh Denny Arnos Kwary. Jakarta: Salemba Empat.

[5.] Hansen, M. E., \& Mowen, M. M. (2013). Cornerstones of Cost Management. Jakarta: Salemba Empat

[6.] Kaplan, R. S., \& Norton, D. P. (1996). The Balanced Scorecard: Translating Strategy Into Action. Massachusetts: Harvard Business School Press.

[7.] Ogungbade, O. I. (2017). Antecedents To Choice of Management Accounting Practices Among Manufacturing Companies in Nigeria. Journal of Economics, Commerce, and Management, Vol V (10), 46-66.

[8.] Suartika, I. M. (2007). Perancangan dan Implementasi Sistem Pengukuran Kinerja dengan Metode Integrated Performance Measurement System. Journal Teknik Industri, Vol 9 (2), hal 131-143 